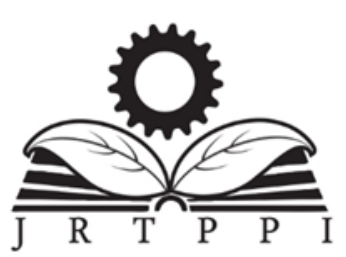

Vol. 10 No. 2 (2019) 16-28

Jurnal Riset

Teknologi Pencegahan Pencemaran Industri

Kementerian

Perindustrian

REPUBLIK INDONESIA

Journal homepage : jrtppi.id

\title{
Low Energy Bacteria Preservation of Extremely Halophilic Archaea Haloferax Lucentense and Haloferax Chudinovii Immobilized using Natural Zeolite
}

\author{
Rizal Awaludin Malik ${ }^{1}$, Nilawati ${ }^{1}$, Novarina Irnaning Handayani ${ }^{1}$, Rame $^{1}$, Silvy Djayanti ${ }^{1}$, Ningsih Ika Pratiwi ${ }^{1}$, Nanik Indah \\ Setianingsih ${ }^{1}$, Nasuka $^{1}$ \\ ${ }^{1}$ Center of Industrial Pollution Prevention Technology, Jl. Ki Mangunsarkoro No. 6 Semarang 50136, Central Java, Indonesia
}

\begin{tabular}{|c|c|}
\hline ARTICLE INFO & $\mathrm{CT}$ \\
\hline $\begin{array}{l}\text { Article history: } \\
\text { Received 02 September } 2019 \\
\text { Received in revised form } 11 \text { November } \\
2019 \\
\text { Accepted } 04 \text { December } 2019 \\
\text { Available online } 16 \text { December } 2019\end{array}$ & $\begin{array}{l}\text { The methods of microbial cells preservation were already known by liquid drying, freeze- } \\
\text { drying, and freezing. Those methods could preserve bacteria cells in a long period of time but } \\
\text { its survivability was relatively low and used relatively high energy during preservation. } \\
\text { Immobilization was known as entrapping, attaching or encapsulating bacterial cells in a } \\
\text { suitable matrix. This research was conducted to know the suitability of zeolite as } \\
\text { immobilization carrier and also as preservation matrix of two halophilic archaea Haloferax } \\
\text { chudinovii and Haloferax lucentense. Variable of this research was the type of the carrier } \\
\text { which was raw zeolite, } 110^{\circ} \mathrm{C} \text { and } 300^{\circ} \mathrm{C} \text { heat-activated zeolite carrier, parameters measured } \\
\text { in this study was physical and chemical of zeolite such as chemical content, Si/Al ratio, surface } \\
\text { area and pore volume, and biochemical assay, bacterial cells numbers after immobilization } \\
\text { and bacterial cells after preservation as bacterial response to the immobilization and } \\
\text { preservation. Heat activation was significantly affecting the zeolite chemical composition, } \\
\text { carrier surface area, and pore volume. Compared to other pretreated zeolite, highest quality } \\
\text { zeolite was obtained in } 110^{\circ} \mathrm{C} \text { pretreated zeolite which has which has } 65,625 \mathrm{~m}^{2} / g r \text { for surface } \\
\text { area } 0,071 \text { cc/gr pore volume and } 5,13 \text { Si/Al ratio. . The bacterial cells obtained after } \\
\text { immobilization process was } 1,8 \times 10^{7} \text { cfu/g, } 3,0 \mathrm{x} 10^{7} \text { cfu/g, and } 2,1 \times 10^{7} \text { for raw zeolite, } 110^{\circ} \mathrm{C} \\
\text { pretreated zeolite and } 300^{\circ} \mathrm{C} \text { zeolite respectively. After } 4 \text { months preservation, the slight } \\
\text { reduction of the bacterial cells was observed. Immobilization halophilic archaeae using zeolite } \\
\text { as carrier was proven as low cost and effective preservation method due to relatively simple } \\
\text { process and unspecific preservation temperature requirements. }\end{array}$ \\
\hline
\end{tabular}

\section{INTRODUCTION}

Halophilic bacteria or halobacteria are known as single cell microorganism inhabit saline environment. Halobacteria are considered as halophilic archae living in hypersaline environment and having pigment ranging from yellow to red. Mostly halophilic archaea are found in crystallization ponds due to high salinity requirement (250$300 \mathrm{~g} / \mathrm{l}$ ) of $\mathrm{NaCl}$ (A Oren, 2010). Halophilic archaea have ability to coupe with high osmolarity pressure due to their

\footnotetext{
${ }^{*}$ Correspondence author.

E-mail : andritr@kemenperin.go.id
}

ability to compensate intercellular osmotic pressure using salt in mechanism and compatible solute (Das sarma, 2001). Halophilic archaea were also known to their ability to survive inside the halite crystal in long period of time (Norton et al., 1993).

Bacteria cells preservation has been known for a long time. Lyophilization or freeze-drying method was the oldest methods used to preserved bacteria cell in which 
bacteria cell was frozen and then dried using freeze drying apparatus (Heckly, 1961). Freeze drying apparatus consisting of vacuum machine, freezing apparatus and drying apparatus, this method has relatively low survival percentage due to extreme temperature applied during its processes and also the requirement of suitable protective media are strictly needed. To obtain maximum preservation time the freeze dried sample must be stored in $1-4^{\circ} \mathrm{C}$ storage or even lower temperature (Kupletskaya and Netrusov, 2011). The limitation of freeze-drying method were very selectively depended on the microorganism characteristic. Preservation of bacterial cell commonly done by refrigeration (storage in $<4^{\circ} \mathrm{C}$ ), ultralow freezer $\left(-86^{\circ} \mathrm{C}\right)$, cryofreezing $\left(-130\right.$ to $\left.-145^{\circ} \mathrm{C}\right)$ this preservation cost high energy to operate.

Zeolite is naturally found in nature and commercially used by many human activities. Zeolite has white-greenish soft minerals, it consists commonly of a tetrahedral crystalline microstructure built from alumina $\left(\mathrm{AlO}_{4}\right)$ and silica $\left(\mathrm{SiO}_{2}\right)$ (Jha, B; Singh, 2016). Zeolite composed in three categories which are extraframework cations, framework and sorbed phase due to its high adsorption properties. Upon incorporation of $\mathrm{Al}$ with $\mathrm{SiO} 2$ the surface of zeolite becomes negatively charged, in this condition extraframework of organic and inorganic cations is needed to made the surface positively charged (Payra and Dutta, 2003). Zeolite is also known to have molecular sieve, ion exchange and catalityc features.

Immobilization is known as a common technique to preserve and improve bacteria activity. Immobilization is microbial engineering by trapping, attaching and encapsulating the enzyme or bacterial cells into a matrix or carrier (Woodward, 1988). The suitable matrix characteristic for immobilizing bacterial cell must have high cell loading capacity, simple and nontoxic for targeted bacteria, mechanically stable, bacteria and matrices were easily separated (Abdelmajeed et al., 2012). Common carriers used for immobilizing bacterial cells are divided into inorganic materials such as zeolite, clay, porous glass, ceramics and organics materials /polymers (Suzana et al., 2015). The advantages of bacterial cell immobilization compared to enzyme immobilization is cheaper due to reduction of the separation process, the possibility of multiple reactions occurred due to various enzymes produced by bacteria cells, and the presence of bacterial biosynthesis that supports the existence of longer or complex chain of enzyme reactions (Jack and Zajic, 1977). Increased ability and biochemical activity of immobilized bacteria are well known, research done by Shindo et al., (2001) investigated continuously ethanol production using Saccharomyces cerevisiae immobilized in inorganic matrices (zeolite) carriers which have twice larger fermentation activity compared to un-immobilized Saccharomyces cerevisiae. In other hands (Omarova et al., 2012) shown that immobilized Rhodococcus spp using organic polymers were used in the degradation of crude and oil products. Many methods used to immobilizing bacteria cell and the most common bacterial cell immobilization was encapsulation using alginate polymer (Zommere and Nikolajeva, 2018). Otherwise, immobilization of bacterial cells could probably has a negative impact to bacterial biochemistry activities.

Immobilization processes are also used to preserve bacteria cells in order to keep the bacteria in perfect condition when it comes to use. Research done by Krumnow et al (2009) obtained that E.Coli and Bacillus subtilis were well preserved for 64 days in accacia gum and pulluan matrices with temperature and humidity variation, thus result are also affected by the bacteria characteristic such as avoid dehydration capability and ability to produce spore. There are many variation of immobilization carriers used for preserving bacteria cells such as sol gel matrix (Nassif et al., 2003) and PVA (Poly Vinyil Alcohol) (Efremenko and Tatarinova, 2007). The matrix selection used in immobilization process are adjusted with the bacteria characteristic and the purpose of immobilization. Bacteria cell immobilization are also has function for maintain bacteria ability to produce specific proteins. Desimone et al (2005) found that E. Coli producer of recombinant proteins were immobilized in silicone oxide matrix and it preserved perfectly in $4{ }^{\circ} \mathrm{C}$ and $20^{\circ} \mathrm{C}$ storage for 60 days. 
Haloferax chudinovii and Haloferax lucentense are an example of halophilic archaea which found in hypersaline environment from Sampang region in Madura Indonesia. Potential use of these haloferax species are still limited due to lack of study about this species. The aim of this research was to obtain information about possibility of low energy preservation of two halo arcahaeae species Haloferax chudinovii and Haloferax lucentense using immobilization method.

\section{METHODS}

\subsection{Carrier Pretreatment, Morphological visualization and quantificationHalophilic bacteria preparation \\ a. Carrier Pretreatment}

The Natural zeolite used as a carrier in this research was obtained from a local chemical store in Semarang. Pretreatment of the carrier used in this research was done by activating the zeolite using heat treatment to remove organic impurities in the zeolite pore. Heat activation was done by heating the zeolite using furnace at $300^{\circ} \mathrm{C}$ for 4 hours (Djaeni et al., 2010) and heating using the oven at $105^{\circ} \mathrm{C}$ for 24 hours (West and Strohfus, 1997), treated zeolite was then cooled in a desiccator.

\section{b. Morphological Visualization and Quantification}

Quantification of immobilization carriers was done using Braunner-Emmet-Teller (BET) method and BarretJoyner-Halenda (BJH) method (Quantachrome instrument), this quantification was to determine zeolite surface area and pore size for each pretreatment variations. Morphological visualization of immobilization carriers and the immobilized sample was done using SEM-EDX (Jeol JSM 6510 Analytical Scanning Electron microscope and JED 2300 EDS for EDX analysis) analysis was carried out to obtain the difference between two heat activation to zeolite physical and chemical properties.

\subsection{Culture preparation and immbilization procedure}

a. Culture Preparation

Extremely halophilic archaea Haloferax chudinovii and Haloferax lucentense strain used in this research was laboratory isolate. Pre-culture was conducted by inoculating each 2 loops pure culture of Haloferax chudinovii and Haloferax lucentens into different sterile conical flask glass filled with $50 \mathrm{ml}$ of modification of extremely halophilic liquid medium consisting $\mathrm{NaCl} 24 \%(\mathrm{w} / \mathrm{v})$, yeast extract $0,25 \mathrm{gr} / \mathrm{l}$, tryptone water $0,5 \mathrm{gr} / \mathrm{l}, \mathrm{MgSO}_{4} .7 \mathrm{H}_{2} \mathrm{O} 20 \mathrm{gr} / \mathrm{l}$, $\mathrm{KCl} 2 \mathrm{gr} / \mathrm{l}$, and trisodium citrate $3 \mathrm{gr} / \mathrm{l}$ (Nilawati et al., 2017), the cultures were incubated and shaked in shaker incubator at $39^{\circ} \mathrm{C}$ for 7 days. The culture Harvested after 7 days incubation and then mixed into $250 \mathrm{ml}$ sterile conical flask and stirred to make the mixture homogenous. The obtained mixture was stirred for $15 \mathrm{~min}$ and counted the cell using total plate count (TPC) method to determine the number of the viable cell, TPC was done by diluting $1 \mathrm{ml}$ of harvested mixed culture and then diluted in series 11 fold in $9 \mathrm{ml}$ sterile distilled water, the number of bacterial were expressed as $\mathrm{CFU} \mathrm{g} \mathrm{g}^{-1}$. Obtained intial culture was $10^{11}$

\section{b. Immobilization Procedure}

The immobilization was carried out by inoculating $50 \mathrm{ml}$ pure culture of Haloferax lucentense and Haloferax chudinovii each in sterile erlenmeyer flasks and then each $10 \mathrm{gr}$ natural and pretreated zeolite as immobilization carrier was added to the culture. Immobilization procedure was done under shaking condition at 200rpm for 24 hours in order to obtain maximum absorption of the cultured cell on the zeolite carrier matrices. Immobilized cells were then harvested by separating supernatant and the culture filtrate and dried in room temperature for 24 hours.

\subsection{Analysis}

a. Biochemical Assay

Biochemical assay of Haloferax lucentense, Haloferax chudinovii, and immobilized Haloferax lucentense and Haloferax chudinovii was determined using Vitek 2 Technology (Biomereux) by culturing $10 \mathrm{w} / \mathrm{v}$ immobilized sample in liquid modified haloferax medium and incubated in shaker incubator in 150rpm for 7 days at $39^{\circ} \mathrm{C}$. The growth cultures then harvested and stored in a sterile glass tube with screw cap and then transferred for biochemical assay. 
b. Viability cell during preservation

The number of viable cell were determined as viable counts (cfu) per gram immobilized sample. After dried in room temperature for 24 hours immobilized Haloferax lucentense and Haloferax chudinovii sample were transferred into a sterile plastic clip and then stored in room temperature for 4 months (Alvarez et al., 2007). Viability cell was done after immobilization process and after 4 months preservation using TPC method with triple replicates for each variation, 1 gram of each immobilized sample were serially diluted $10^{-9}$ fold dilution and each dilution was mixed using vortex to make homogeneous suspension, then $1 \mathrm{ml}$ aliquot of $10^{-4}-10^{-9}$ diluttion were plated in solid modified haloferax medium which was then incubated for 21 days at $39^{\circ} \mathrm{C}$.

\section{RESULT AND DISCUSSION}

\subsection{Physical and chemical characteristic of carriers}

Zeolite is a porous material which consists of $\mathrm{Al} 2 \mathrm{SO} 3$ and $\mathrm{SiO} 2$ bonded together in such way formed tetrahedral structure (Mery et al., 2012). CaCO3, organic and water vapor are the most common impurities found in zeolites that could cover the porous that led to decreasing the zeolites ability to adsorb targeted substances (Fuoco, 2012). Heat treatment and chemical additionare the most common pretreatment done to activate and or enhance zeolite ability to adsorb liquid and gasses. Chemically activated zeolite has several disadvantages when used as bacteria cell immobilization carrier which was longer activation process, the possibility of hazardous chemical left in the carrier matrices that has a negative effect on immobilized bacteria.

Table 1 shows the quantification of zeolite composition in all pretreatment variable used in this research. Carbon content considered as impurities in zeolite and it has significantly decreased due to heat treatment applied, it decreased from $54,41 \%$ to $13,07 \%$ and $15,45 \%$ in $110^{\circ} \mathrm{C}$ pretreatment and $300^{\circ} \mathrm{C}$ pretreatment respectively. In other hands physical heat treatment increased the percentage of $\mathrm{SiO}_{2}$ and $\mathrm{Al}_{2} \mathrm{O}_{3}$, initial percentage of raw zeolite was $32,48 \%$ and $5,88 \%$ while the $110^{\circ} \mathrm{C}$ and $300^{\circ} \mathrm{C}$ pretreated zeolite has increased twice which was $64,89 / 12,47 \%$ and $62,79 \% / 11,82 \%$ respectively. The increasing of $\mathrm{SiO}_{2} / \mathrm{Al}_{2} \mathrm{O}_{3}$ percentage occurred because of elimination or reduction of organic impurities and evaporated water vapor which trapped in zeolite pore by heat treatment. Heat treatment applied in this experiment was not impacting other impurities such as $\mathrm{CaO}$ and $\mathrm{K}_{2} \mathrm{O}$ minerals this phenomenon occurred because the heat applied was not high enough to decompose the substances due to zeolite calcination temperature was ranging between $1200-1300^{\circ} \mathrm{C}$ (Shindo et al., 2001). The importance of heat tratment was to enhance the $\mathrm{Ca}+\mathrm{K}+$, $\mathrm{Na}+$ ions in zeolite, thus needed for making the zeolite surface become more positively charged to accomodate adhesion or adsorption of negatively charged bacteria cell wall. Calcination was not needed in this experiment because of the physical and chemical properties needs for immobilizing bacteria cell was not specifically required, the importance of heat treatment was reduction of organic and vapor impurities that could caused blocking or inhibition of bacterial adsorption or adhesion.

Table 1. Chemical Composition of Carriers

\begin{tabular}{llll}
\hline \multicolumn{1}{c}{ Element } & \multicolumn{2}{c}{ Mass \% } \\
& \multicolumn{2}{c}{ Raw } & \multicolumn{1}{c}{$110^{\circ} \mathrm{C}$} \\
Zeolite & $\begin{array}{l}\text { Pretreated } \\
\text { zeolite }\end{array}$ & $\begin{array}{l}300^{\circ} \mathrm{C} \\
\text { Pretreated } \\
\text { zeolite }\end{array}$ \\
\hline $\mathrm{C}$ & 54,41 & 13,07 & 15,45 \\
$\mathrm{Na} 2 \mathrm{O}$ & 0,96 & 2,02 & 1,64 \\
$\mathrm{MgO}$ & 0,29 & 0,57 & 0,75 \\
$\mathrm{Al} 2 \mathrm{O} 3$ & 5,88 & 12,67 & 11,82 \\
$\mathrm{SiO} 2$ & 32,48 & 64,89 & 62,79 \\
$\mathrm{~K} 2 \mathrm{O}$ & 0,89 & 2,13 & 1,84 \\
$\mathrm{CaO}$ & 1,38 & 2,57 & 2,44 \\
$\mathrm{FeO}$ & 0,9 & 2,08 & 2,13 \\
$\mathrm{CuO}$ & 1,53 & - & 1,13 \\
$\mathrm{ZrO} 2$ & 1,29 & - & - \\
$\mathrm{Si} / \mathrm{Al}$ ratio & 5,52 & 5,12 & 5,31 \\
\hline
\end{tabular}




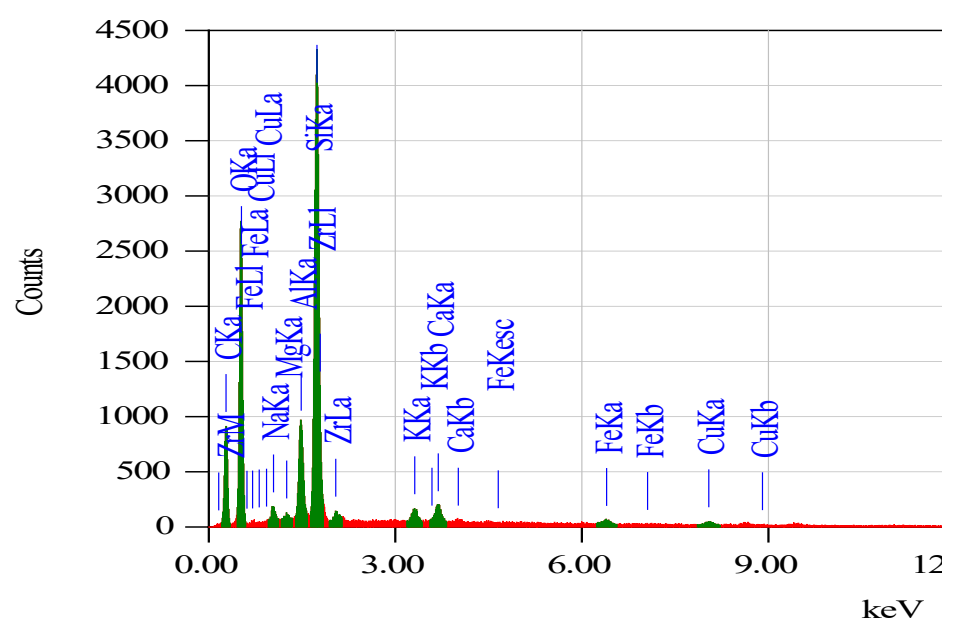

(a)

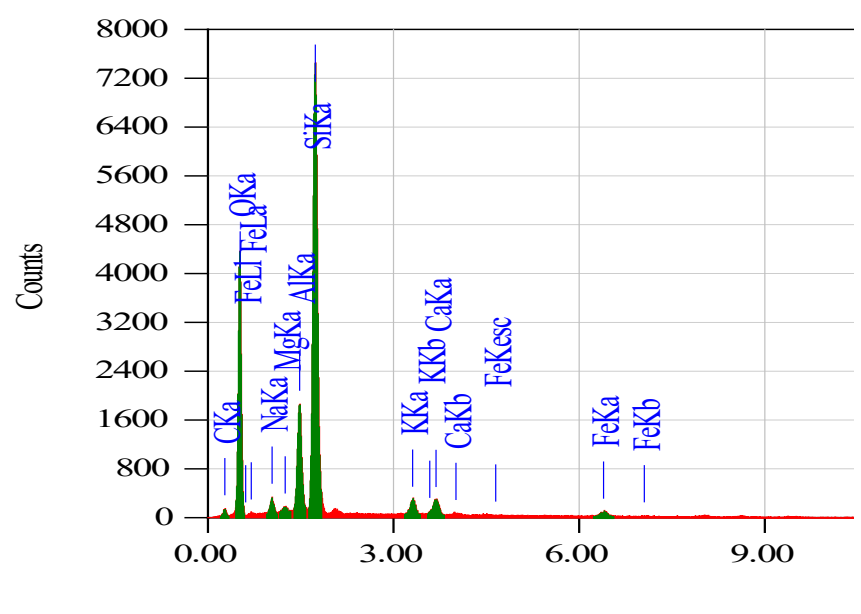

(b)

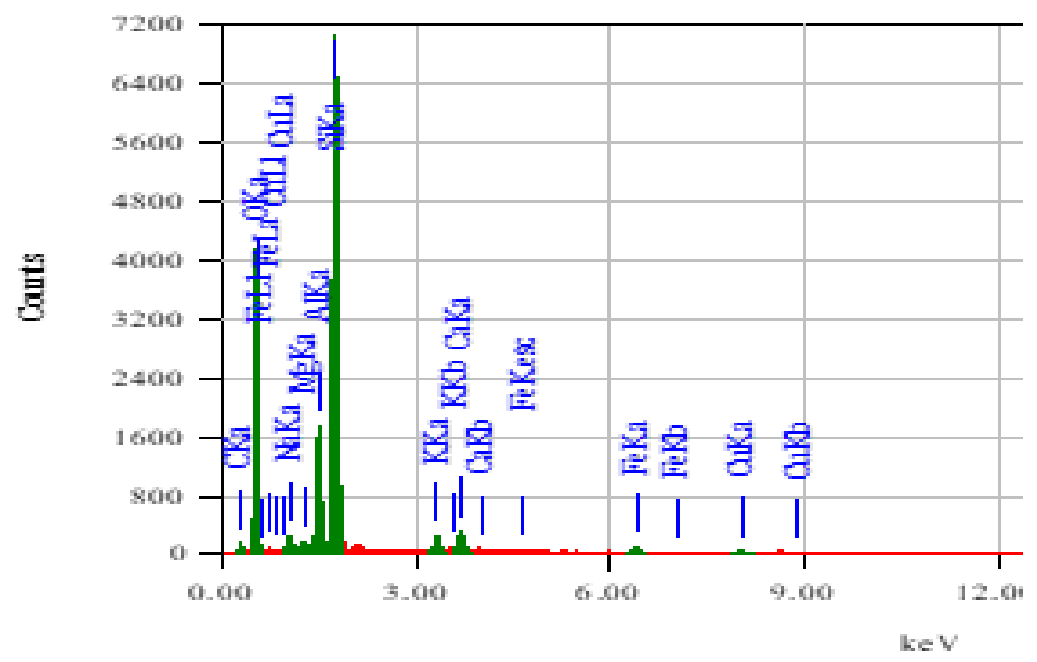

(c)

Figures 1. EDX visualization Raw Zeolite (a), Pretreated $110^{\circ} \mathrm{C}$ zeolite (b) and $300^{\circ} \mathrm{C}$ (c)

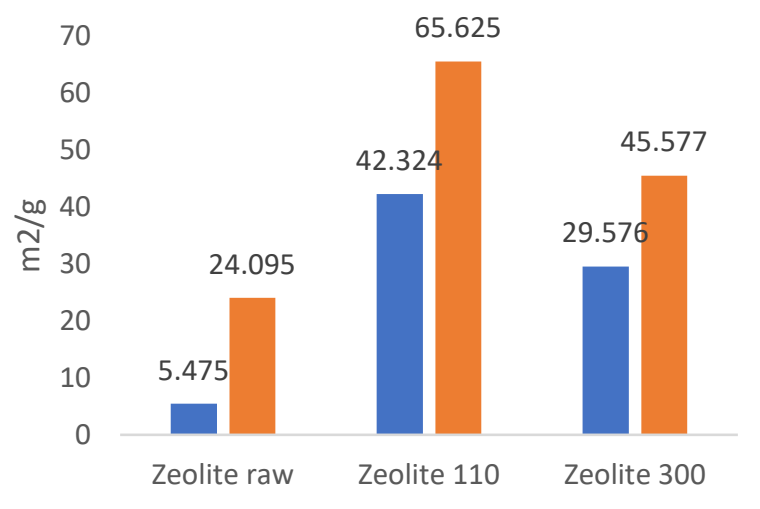

- Surface area BJH (m2/g) — Surface area BET (m2/g)

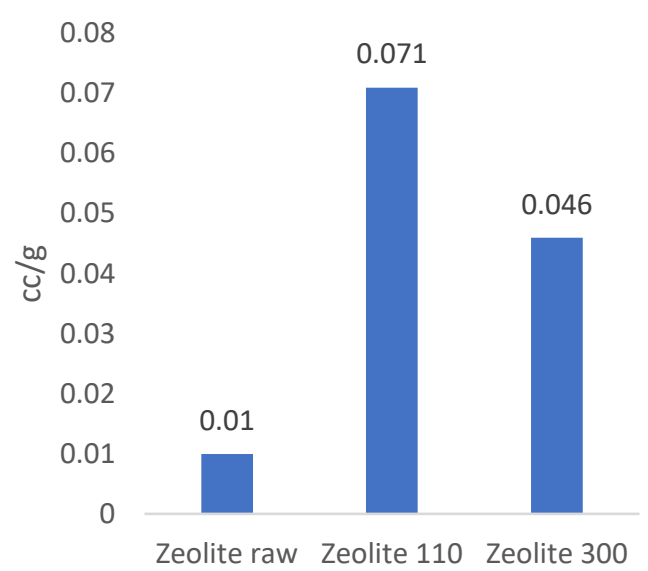

(b)

Figures 2. Physical properties of carrier, Carrier surface area (a) and Carrier pore volume (b) 
Another impact affected by heat treatment was $\mathrm{Si} / \mathrm{Al}$ ratio, untreated zeolite has $5,52 \mathrm{Si} / \mathrm{Al}$ ratio, $110^{\circ} \mathrm{C}$ and $300^{\circ} \mathrm{C}$ heat treated zeolite has $\mathrm{Si} / \mathrm{Al}$ ratio 5,12 and 5,52 respectively, the lower ratio of $\mathrm{Si} / \mathrm{Al}$ and higher $\mathrm{SiO}_{2} / \mathrm{Al}_{2} \mathrm{O}_{3}$ content means higher quality of the zeolite (Mustain et al., 2014). Hydrophobicity and ion exchange capacity of zeolite could be known from its SiAl ratio, higher ratio means higher hydrophobicity and lower ion exchange capacity (Kubota et al., 2008). Si/Al ratio are also affect zeolite pore shape and its distribution. Zeolite modification could be done by physical or chemical treatment or both depend on needs, especially Modification were needed to obtain specific shape and size of zeolite pore. For example, zeolite modified to become nano-pore zeolite was used as immobilization carrier of $\alpha$-amylase enzyme (Talebi et al., 2016). Another physical properties affected by heat activation was zeolite surface area and pore volume.

Figures 2 shows the BET and BJH surface area and pore volume analysis of untreated and treated zeolite carrier. Since the organic impurities were reduced and the water evaporated due to heat application the surface area of the carrier was increased it was confirmed by the BET surface area in mother carrier (raw zeolite) was $24,095 \mathrm{~m}^{2} / \mathrm{g}$ and the highest surface area was $110^{\circ} \mathrm{C}$ pretreated zeolite which has $65,625 \mathrm{~m}^{2} / \mathrm{g}$ and followed by $300^{\circ} \mathrm{C}$ pretreated zeolite which has surface area $45,577 \mathrm{~m}^{2} / \mathrm{g}$. Surface area analysis using the $\mathrm{BJH}$ method has the same trends with BET method. Highest $\mathrm{BJH}$ surface area was occurred in $110^{\circ} \mathrm{C}$ treated zeolite which has $42,324 \mathrm{~m}^{2} / \mathrm{g}$, followed by $300^{\circ} \mathrm{C}$ treated zeolite and zeolite raw which has $29,576 \mathrm{~m}^{2} / \mathrm{g}$ and $5,475 \mathrm{~m}^{2} / \mathrm{g}$ respectively. Increased pore volume has same trend with surface area, pretreated $110^{\circ} \mathrm{C}$ zeolite has 0,071 $\mathrm{cc} / \mathrm{g}$ it was the highest volume compared to two others carriers.

\subsection{Immobilzation}

Immobilization bacterial cells onto zeolites matrix has been investigated by many reseracher, Weiß et al., (2013) investigated that anaerobic bacteria grows and colonized in activated zeolites, another work done by Hrenovic et al., (2011) has investigated phospate- accumulating bacterium A. Junii could immobilized in zeolitized tuff.

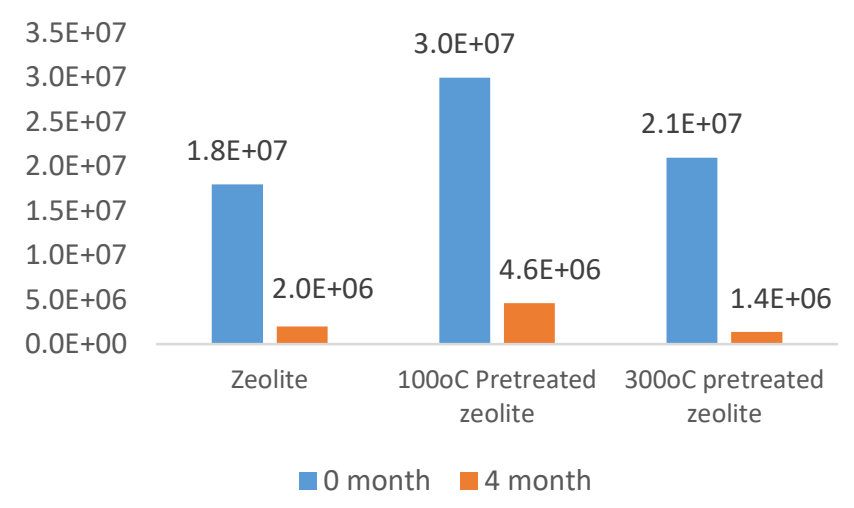

Figure 3. Number of immobilized bacteria cells (Cfu) in different zeolite carriers

After $24 \mathrm{H}$ of bacterial immobilization process and then dried achieved natural zeolite has the lowest number of bacteria which was $1,8 \times 107 \mathrm{cfu} / \mathrm{g}$ and followed by $300 \mathrm{oC}$ pretreated zeolite with $2,1 \times 107 \mathrm{cfu} / \mathrm{g}$. The highest immobilized bacteria cell was achieved using $110 \mathrm{oC}$ pretreated zeolite as immobilization carrier which has the number of bacteria 3,0 x $107 \mathrm{cfu} / \mathrm{g}$. The result After 4 months preservation observed that reduction of bacterial cell in immoblized carrier were occurred in all carrier variations, raw zeolite carrier was reduced to $2 \times 106 \mathrm{cfu} / \mathrm{gr}$, $110 \mathrm{oC}$ pretreated carrier was $4,5 \times 106 \mathrm{cfu} / \mathrm{gr}$ and $300 \mathrm{oC}$ pretreated zeolite was $1,4 \times 106 \mathrm{cfu} / \mathrm{gr}$. Reduction of viable cells number was normally happened during initial preservation. Previous research done by (Sakane et al., 1992) found that several halophilic archaebacteria preserved using liquid drying method could survive approximately to more than 3 years at $5 \mathrm{oC}$ storage but reduced survival rates was still occurred and cell viability was reduced until 2 weeks preservation but relatively stable after 2 weeks. Preservation using liquid drying method has several disadvantages such as obligation to use protective media as immobilization carrier, the number of viable cells after immobilization process was regarded low due to extreme heat exposure during liquid drying process, and the immobilized cell must be stored at $5 \mathrm{oC}$ to gain maximum preservation condition. Compared to another research, Alvarez et al (2007) obtained the number of viability cell of 
E. Coli immobilized in silica oxide and its derivate which stored at $20 \mathrm{oC}$ has a reduction variying from 102 to 103 $\mathrm{cfu} / \mathrm{ml}$ in 60 days preservation.

SEM visualization of un-immobilized and immobilized carriers used in this research were presented in Figure 4. Under microscopic visualization, halophilic archae used in this research has irregular shape and attached each others with slime-like substances (fig 4.g), those slime-like covering haloarchaea microorganism was exopolymer secreted by halophilic archaea microorganism as compatible-solute mechanism to adapt with hypersaline and other environmental stresses (Dassarma and Dassarma, 2016). Halophilic archaea also has "salt in" and "salt out" mechanism for osmoregulation or osmo-protection in order to balance the osmotic pressure with the extracellular environment (Vreeland, 2012). Salt-in or salt-out mechanism is a srtategy to accumulating inorganic ions escpecially $\mathrm{K}+$ in their cytoplasm or secreting inorganic ions to their environment in order to maintain their ion gradient equilibrum (Kunte, 2009). Salt-in and salt-out mechanism works not only for osomregulation purpose but also for intracellular enzymatic activity (Empadinhas and Costa, 2008).

Figure 4a is SEM visualization of natural zeolite before immobilized with halophilic archaea, compared to other carriers, natural zeolite surface and pores covered by impurities. Pretreated $110^{\circ} \mathrm{C}$ and $300^{\circ} \mathrm{C}$ zeolite has more clearer surface and pore (figure $4 \mathrm{c}$ and $4 \mathrm{e}$ ). Immobilized bacteria was colonizing mostly in the surface area of the carrier, some colony in pore was observed but not fully covering or plugging the pores. The presence of Haloferax chudinovii and Haloferax lucentense were marked with cubic shape or cubic like crystal which specifically produced by extreme halophilic archaea due to salt in and salt out mechanism (Castanier et al., 1992; Malik et al., 2019). In the hypersaline and dry environment the presence of halophilic archaea and formation of $\mathrm{NaCl}$ crystal or ooids were inefitable due to osmoregulation mechanism described below, this phenomenon happend due to drying in immobilization process. When the formation of $\mathrm{NaCl}$ crystal some fluid brine would form fluid inclusion, in the presece of halophilic archaea when the fluid inclusion was formed the halophilic archaea would use it as a shelter to survive in unfavorable condition (Lowenstein et al., 2011).

Figure 4 shown that immobilization was done mainly by adhesion mechanism, adsorption only happend due to the presence of pores in zeolite that utilize capillary pressure so it pull the culture (liquid phase) near onto zeolite surface. Most of gram-negative bacteria has negative charge while the zeolite it self has the same ionic charge, but negatively charged bacteria could also adhere on negatively charged materials (Klein and Ziehr, 1990), another possibility for bacteria to attached in zeolite surface was heat treatment that significantly turn the ionic charge of zeolite surface from negatively charged to positively charged . Adhesion or attachment of Halophilic archaea on the surface of zeolite carrier are also supported by the presence of S-layer proteins on haloarchaea cell wall that help the bacteria to attach on solid surface (Fendrihan et al., 2011). Another mechanism of halophilic archaea adhesion was exopolymers secreted by halophilic microorganism which surrounds the bacteria cells or colony that makes the bacteria attached to the zeolite surface.

Physiological and biochemical changes during immobilization may occurred due to unfavorable condition (Chauhan and Singh, 1999). The changes of Halophilic archaea biochemical pathways was investigated when trapped in halite fluid inclusion (Zerulla et al., 2014). Biochemical activity before and after immobilization procces was obtained by biochemical assay and shown in table 2.

Biochemical assay shown that immobilization of halophilic archaea Haloferax chudinovii and Haloferax lucentense was not changing halophilic arcahaea metabolism ability (Table 2). halophilic archaeae enzymatic activity such as Lactatae alcalinization, Lipase enzyme, Tyrosine arylmidase, and ellman test was present in all immobilized carriers, only succinate activity who not present. From the data above shown that immobilization carriers and immobilization process were not giving a negative impact to halophilic archaea biochemical activity. Otherwise after immobilization another enzymatic activity 
who were not present in single culture enzymatic assay was present in immobilized culture assay such as Phospatase, Fermantation procces, adonitol, A-glukosidase enzyme activity. Thus data confirmed that immobilization process

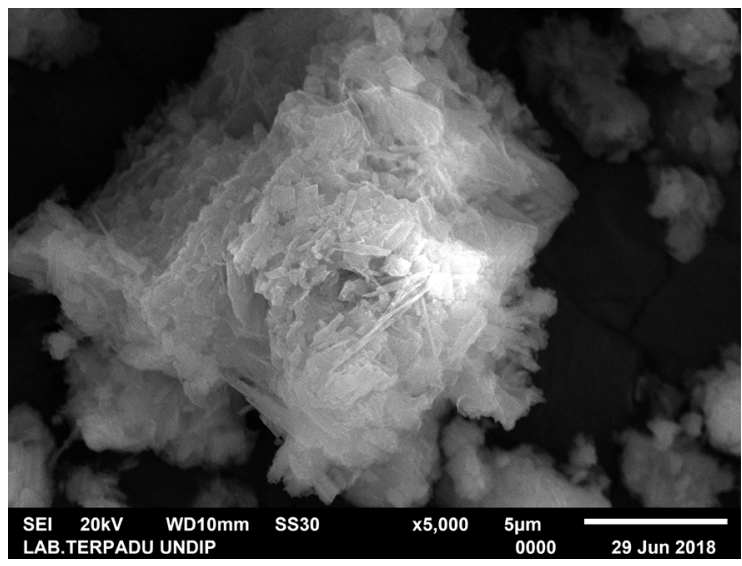

(a)

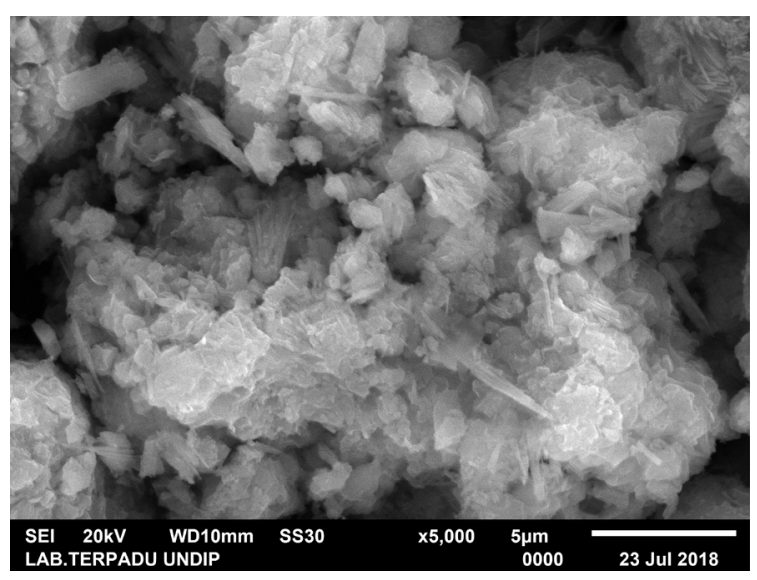

(c)

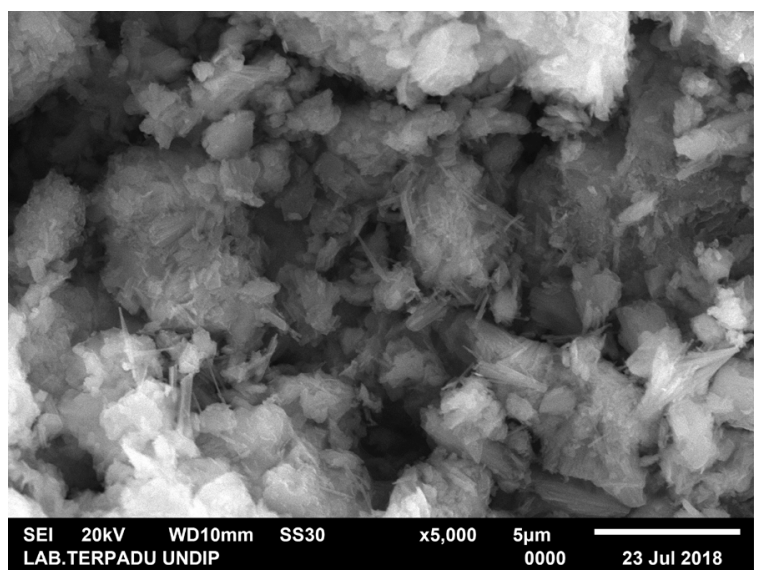

(e) was enhancing bacteria ezymatic activity. Advantage of bacterial cells immobilization is the stability of protein and enzyme and this is not limiting their industrial utilization (Alfani et al., 1994).

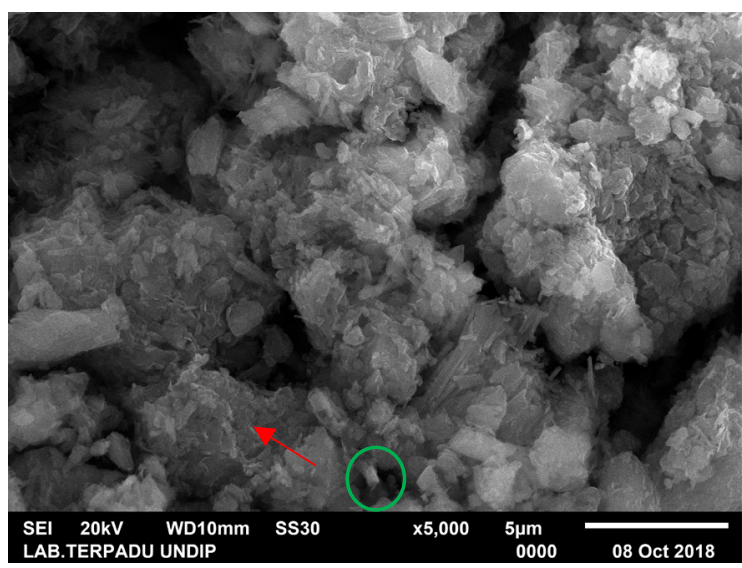

(b)

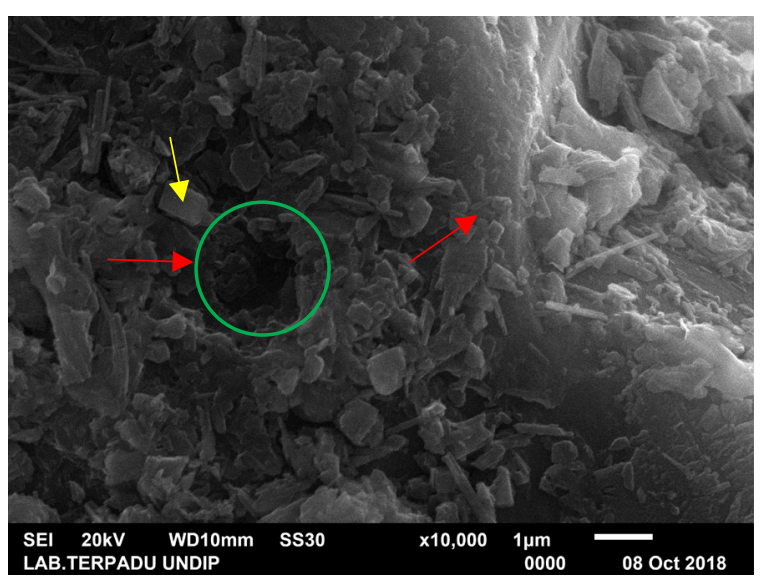

(d)

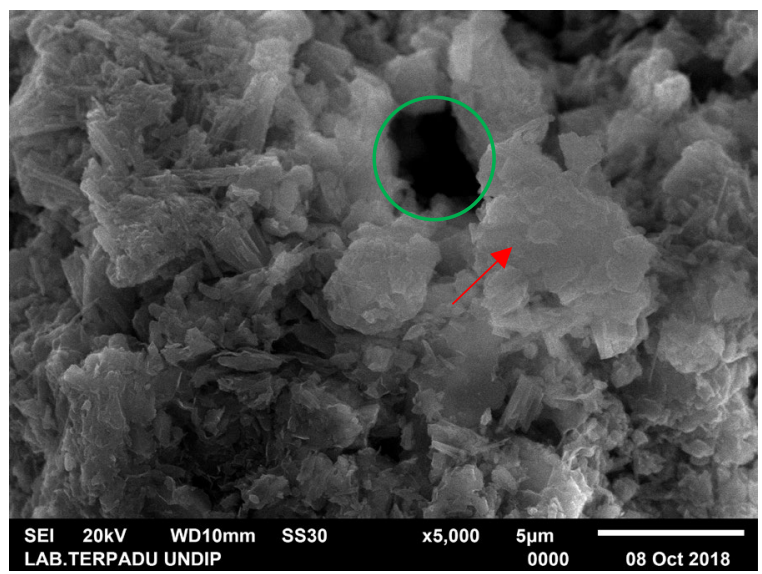

(f) 


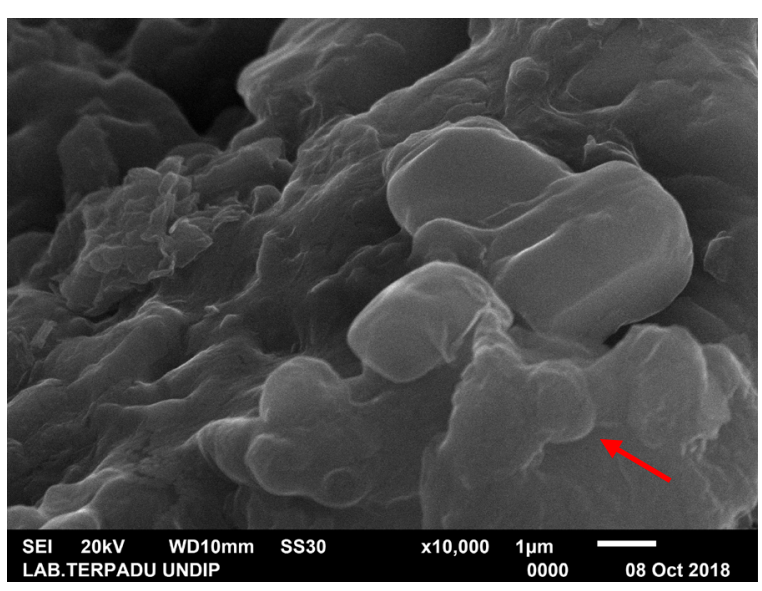

(g)

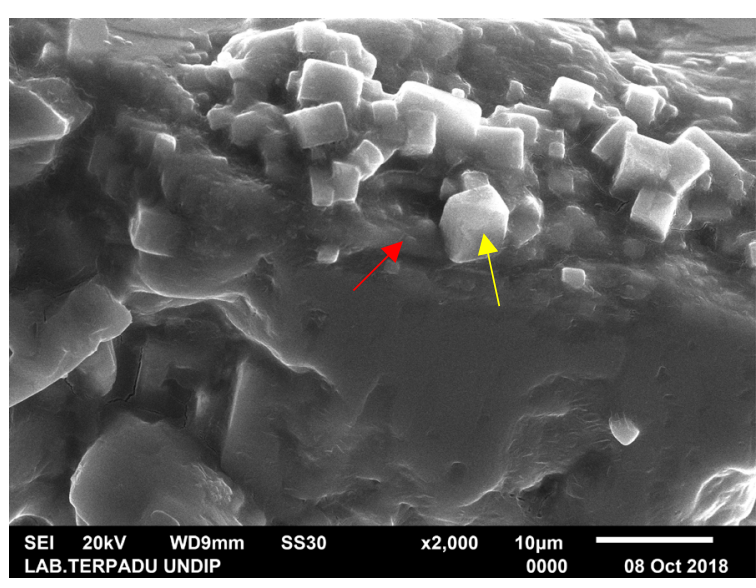

(h)

Figure 4. (a) Un immobilized Raw zeolite (b) immobilized Halophilic bacteria in raw zeolite matrices (c) Un immobilized $110^{\circ} \mathrm{C}$ pretreated zeolite (d) immobilized $110^{\circ} \mathrm{C}$ pretreated zeolite (e) Un immobilized $300 \mathrm{oC}$ pretreated zeolite (f) immobilized $300^{\circ} \mathrm{C}$ pretreated zeolite (g) SEM visualization of Haloferax chudinovii and Haloferax lucentense used in this work (h) $\mathrm{NaCl}$ crystal in Halophilic archaea colony; red arrow: Halophilic arcaea; Yellow arrow: $\mathrm{NaCl}$ crystal (cubic shape); green circle: pores

Table 2. Biochemical assay

\begin{tabular}{|c|c|c|c|c|c|c|c|}
\hline \multirow[t]{2}{*}{ No. } & \multicolumn{2}{|r|}{ Test Parameter } & \multicolumn{5}{|c|}{ Isolate / sample variation } \\
\hline & Code & $\begin{array}{l}\text { Measured } \\
\text { parameter/activity }\end{array}$ & $\begin{array}{l}\text { Haloferax } \\
\text { lucentense }\end{array}$ & $\begin{array}{l}\text { Haloferax } \\
\text { chudinovii }\end{array}$ & $\begin{array}{l}\text { Immobilized } \\
\text { in zeolit } \\
\text { carrier }\end{array}$ & $\begin{array}{l}\text { Immobilized } \\
\text { cell in } 110^{\circ} \mathrm{C} \\
\text { pretreated } \\
\text { Zeolit }\end{array}$ & $\begin{array}{l}\text { Immobilized } \\
\text { cell in } 300^{\circ} \mathrm{C} \\
\text { pretreated } \\
\text { Zeolit }\end{array}$ \\
\hline 1. & ILATk & $\begin{array}{l}\text { L-Lactate } \\
\text { alkalinization }\end{array}$ & + & + & $(-)$ & + & + \\
\hline 2. & BGLU & B-Glukosidase & $(-)$ & - & - & - & $(-)$ \\
\hline 3. & Lip & Lipase & + & + & + & + & + \\
\hline 4. & $\mathrm{ADO}$ & Adonitol & - & - & + & - & + \\
\hline 5. & AGLU & A-Glukosidase & $(-)$ & - & + & + & + \\
\hline 6. & SUCT & Succinate & - & + & - & - & - \\
\hline 7. & dMAN & D-Mannitol & - & - & $(-)$ & - & - \\
\hline 8. & TyrA & $\begin{array}{l}\text { Tyrosine } \\
\text { Arylamidase }\end{array}$ & + & + & + & + & + \\
\hline 9. & ELLM & Ellman test & + & + & + & + & + \\
\hline 10. & CMT & Courmarate & - & - & + & - & - \\
\hline 11. & OFF & $\begin{array}{l}\text { Fermentation/glucos } \\
\text { e }\end{array}$ & - & - & $(-)$ & - & + \\
\hline 12. & PHOS & Phospatase & - & - & - & - & + \\
\hline
\end{tabular}




\subsection{Survivalability of Halophilic archaea Haloferax chudinovii and Haloferax lucentense}

The aim of Immobilization procedure is to preserve tergeted bacteria into selected carriers. Almost all bacteria known could be preserved when it become dormant. Dormant bacteria has very slow metabolic and other biochemistry activity which impact on decreased cell division rates. Survivalability of immobilized Haloferax lucentense and Haloferax chudinovii in zeolite carrier happend due to the ability of halophilic archaea to survive in unvaforable or starvation condition (Winters et al., 2015). Exopolymer secreted by halophilic archaea were also affect the survivalability of halophilic archaea during preservation due to formation of halophilic archaea biofilm and keeping the cell together in a three dimensional structure (Toyofuku et al., 2016). Biofilm formation are considered as strategy for bacterial survivalability, since biofilms protect microorganism from variable environmental conditions (Zur et al., 2016). The preservation condition in this research were placed under room temperature in closed pastic clip which immobilized halophilic archaea is on dry state. Halophilic archaea survival in dry environment was already known (Aharon Oren, 1994), also halophilic archaea enzymatic proteins were adapt to heat and dry environment and this phenomenon made halophilic archaea could survive in dry environment for long period of time (Tehei et al., 2002).

Due to the presence of exopolymer that bind and covering the bacteria together, thus promote reduction of dehydration in bacteria micro envirnoment which avoiding bacteria to environmental stress so the survivalability of Haloferax lucentense and Haloferax chudinovii were remain high. Another mechanism of survivalability of Haloferax chudinovii and Haloferax lucentense were the formation of crystal inclusion in conjunction with saline water that trapped the bacteria inside and survive in prolonged preservation. The survivalability of immobilized bacteria was depend on the method, carriers or immobilization matrices used and targeted bacteria. All of the three points mention before have mutual functions in order to keep bacteria survivalability during post immobilization.

\section{CONCLUSION}

The numbers of viable cell was relatively high during 4 months preservation in room temperature. Heat activation of the carrier was changing its chemical and physical properties but it seems to be uneffecting bacterial survivalbility or the numbers of attached bacteria. Immobilization and preservation prcedure done in this reserach was not affecting bacterial biochemistry ability. Immobilization method using zeolite as carrier was proven to be used as suitable low cost preservation method for halophilic archaea Haloferax lucentense and Haloferax chudinovii since the immobilization method was simple and preservation condition do not need special (temperature) condition.

\section{ACKNOWLEDGEMENT}

This reserach was fully funded by Industrial research and development agency, Indonesia ministry of industry (DIPA 2018). Special thanks to head of Centre of industrial pollution prevention Technology and microbiology laboratory who was supporting this reserach.

\section{REFERENCES}

Abdelmajeed, N. A., Khelil, O. A., and Danial, E. N. 2012. Immobilization technology for enhancing bioproducts industry. African J. Biotechnol., 11(71), 13528-13539. https://doi.org/10.5897/AJB12.547

Alfani, F., Cantarella, M., Cantarella, F., Gallifuoco, A., and Colella, C. 1994. Synthetic zeolites as carrier for enzyme immobilization in laboratory-scale fixed- bed columns'. Stud. Surf. Sci. Catal., 84, 1115-1122.

Alvarez, G. S., Desimone, M. F., and Diaz, L. E. 2007. Immobilization of bacteria in silica matrices using citric acid in the sol - gel process, 1059-1064. https://doi.org/10.1007/s00253-006-0580-6

Castanier, S., Perthuisot, J. P., Rouchy, J. M., Maurin, A., and Guelorget, O. 1992. Halite ooids in Lake Asal, 
Djibouti: Biocrystalline build-UPS. Geobios, 25(6), 811-821. https://doi.org/10.1016/S00166995(92)80063-J

Chauhan, S., and Singh, S. 1999. Immobilization caused physiological and biochemical changes in $\mathrm{NaCI}$ resistant $(\mathrm{NaCl})$ mutant strain of diazotrophic cyanobacterium Anabaena variabilis. Indian J. Exp. Biol., 37, 696-700.

Das sarma, S. 2001. Halophiles. In Encyclopedia of Life Science (Vol. 1, pp. 1-9). Nature Publishing Group.

Dassarma, S., and Dassarma, P. 2016. Halophiles and their enzymes: negativity put to good use. Curr Opin Microbiol., $\quad 8847(25), \quad 120-126$. https://doi.org/10.1016/j.mib.2015.05.009.Halop hiles

Desimone, M. F., Marzi, M. C. De, Copello, G. J., Fernández, M. M., Malchiodi, E. L., and Diaz, L. E. 2005. Efficient preservation in a silicon oxide matrix of Escherichia coli, producer of recombinant proteins, 747-752. https://doi.org/10.1007/s00253-005-1912-7

Djaeni, M., Kurniasari, L., Purbasari, A., and Sasongko, S. B. 2010. Activation of Natural Zeolite as Water Adsorbent for Mixed-Adsorption Drying. Int. Conf. Mater. Eng., (November), 25-28.

Efremenko, E. N., and Tatarinova, N. I. 2007. The effect of long-term preservation of microbial cells immobilized in poly(vinyl alcohol) cryogel on their viability and biosynthesis of target metabolites. Mikrobiologiia, $\quad$ 76(3), 383-389. https://doi.org/10.1134/S0026261707030113

Empadinhas, N., and Costa, M. S. 2008. Osmoadaptation mechanisms in prokaryotes: distribution of compatible solutes. Int. Microbiol., 11, 151-161. https://doi.org/10.2436/20.1501.01.55

Fendrihan, S., Legat, A., Pfaffenhuemer, M., Gruber, C., Weidler, G., Gerbl, F., and Stan-lotter, H. 2011. Europe PMC Funders Group Extremely halophilic archaea and the issue of long-term microbial survival. Eur. PMC Funders Gr., 5, 203-218. https://doi.org/10.1007/s11157-006-0007-

y.Extremely

Fuoco, D. 2012. A New Method for Characterization of Natural Zeolites and Organic Nanostructure Using Atomic Force Microscopy, 79-91. https://doi.org/10.3390/nano2010079

Heckly, R. J. 1961. Preservation of Bacteria by Lyophilization, (1935), 1-76.

Hrenovic, J., Ivankovic, T., Tibljaš, D., and Roži, M. 2011. Zeolitized tuff as a carrier of bacteria. In Proceedings of the 4th slovenian-croatian symposium on zeolites (pp. 20-23).

Jack, T. R., and Zajic, J. E. 1977. The immobilization of whole cells. Adv. Biochem. Eng. Vol. 5, 125-145. https://doi.org/10.1007/bfb0008744

Jha, B; Singh, D. . 2016. Basics of Zeolites. In Fly Ash Zeolites (pp. 5-31). Springer International Publishing. https://doi.org/10.1007/978-981-101404-8

Klein, J., and Ziehr, H. 1990. Immobilization of microbial cells by adsorption. J. Biotechnol., 16, 1-16.

Krumnow, A. A., Sorokulova, I. B., Olsen, E., Globa, L., Barbaree, J. M., and Vodyanoy, V. J. 2009. Preservation of bacteria in natural polymers. J. Microbiol. Methods, 78(2), 189-194. https://doi.org/10.1016/j.mimet.2009.05.017

Kubota, M., Nakabayashi, T., Matsumoto, Y., Shiomi, T., Yamada, Y., Ino, K., ... Sakaguchi, K. 2008. Selective adsorption of bacterial cells onto zeolites. Colloids Surfaces B Biointerfaces, 64(1), 88-97. https://doi.org/10.1016/j.colsurfb.2008.01.012

Kunte, H. J. 2009. Osmoregulation in Halophilic Bacteria. In Extremophiles (Vol. II).

Kupletskaya, M. B., and Netrusov, A. I. 2011. Viability of lyophilized microorganisms after 50-year storage. Microbiology, $\quad 80(6), \quad 850-853$. https://doi.org/10.1134/S0026261711060129

Lowenstein, T. K., Schubert, B. A., and Michael, N. 2011. Microbial communities in fluid inclusions and long-term survival in halite. GSA Today, 21(1), 19. https://doi.org/10.1130/GSATG81A.1 
Malik, R. A., Handayani, N. I., Nilawati, Rame, Djayanti, S., Pratiwi, N. I., and Setyaningsih, N. I. 2019. Aplikasi Bakteri Halofilik Berwarna Merah Terimmobilisasi Dalam Meningkatkan Kualitas Garam Dalam Proses Produksi Garam Berbasis Air Laut (pp. 224-231). Surakarta.

Mery, C., Guerrero, L., and Alonso-gutierrez, J. 2012. Evaluation of natural zeolite as microorganism support medium in nitrifying batch reactors: Influence of zeolite particle size Journal of Environmental Science and Health, Part A : Toxic I Hazardous Substances and Environmental Engineering Evaluation of. J. Environ. Sci. Heal., 47 , 420-427. https://doi.org/10.1080/10934529.2012.646129

Mustain, A., Wibawa, G., Nais, M. F., and Falah, M. 2014. Synthesis of zeolite $\mathrm{NaA}$ from low grade (high impurities) Indonesian natural zeolite. Indones. J. Chem., 14(2), 138-142. https://doi.org/10.22146/ijc.21250

Nassif, N., Roux, C., Coradin, T., Rager, M. N., Bouvet, O. M. M., and Livage, J. 2003. A sol-gel matrix to preserve the viability of encapsulated bacteria. J. Mater. Chem., 13(2), 203-208. https://doi.org/10.1039/b210167j

Nilawati, Marihati, and Malik, R. A. 2017. Kemampuan isolat bakteri haloferax spp dalam meningkatkan kemurnian garam $\mathrm{NaCl}$ pada proses kristalisasi.pdf. J. Ris. Teknol. Pencegah. Pencemaran Ind., 8(2), 92-103.

https://doi.org/https://doi.org/10.21771/jrtppi.20 17.v8.no2

Norton, F., Mcgenity, J., and Grant, D. 1993. Archaeal halophiles ( halobacteria) from two British salt mines. J. Gen. Microbiol., (139), 1077-1081.

Omarova, E. O., Lobakova, E. S., Dolnikova, G. A., Nekrasova, V. V., Idiatulov, R. K., Kashcheeva, P. B., ... Dedov, A. G. 2012. Immobilization of bacteria on polymer matrices for degradation of crude oil and oil products. Moscow Univ. Biol. Sci. Bull.,67(1),24-30. https://doi.org/10.3103/s0096392512010063

Oren, A. 2010. THOUGHTS ON THE “ MISSING LINK " BETWEEN SALTWORKS BIOLOGY AND SOLAR SALT QUALITY. Glob. Nest J., 12(4), 417-425.

Oren, Aharon. 1994. The ecology of the extremely halophilic archaea. FEMS Microbiol. Rev., 13, 415-439. https://doi.org/10.1016/01686445(94)90063-9

Payra, P., and Dutta, P. K. 2003. Zeolites: A Primer. In Zeolites (pp. 1-19).

Sakane, T., Fukuda, I., Itoh, T., and Yokota, A. 1992. Long-term preservation of halophilic archaebacteria and thermoacidophilic archaebacteria by liquid drying. J. Microbiol. Methods, 16(4), 281-287. https://doi.org/10.1016/0167-7012(92)90080-N

Shindo, S., Takata, S., Taguchi, H., and Yoshimura, N. 2001. Development of novel carrier using natural zeolite and continuous ethanol fermentation with immobilized Saccharomyces cerevisiae in a bioreactor. Biotechnol. Lett., 23, 2001-2004.

Suzana, C. udia S. M., Claudia, M., a, M., Larissa Guedes Fiuacute za, M. C. o, and ra, T. dde S. 2015. Immobilization of microbial cells: A promising tool for treatment of toxic pollutants in industrial wastewater. African J. Biotechnol., 12(28), 44124418. https://doi.org/10.5897/ajb12.2677

Talebi, M., Vaezifar, S., Jafary, F., Fazilati, M., and Motamedi, S. 2016. Stability Improvement of Immobilized $\alpha$-amylase using Nano Pore Zeolite, 14(1). https://doi.org/10.15171/ijb.1261

Tehei, M., Franzetti, B., Maurel, M. C., Vergne, J., Hountondji, C., and Zaccai, G. 2002. The search for traces of life: The protective effect of salt on biological macromolecules. Extremophiles, 6(5), 427-430. https://doi.org/10.1007/s00792-0020275-6

Toyofuku, M., Inaba, T., Kiyokawa, T., Obana, N., Yawata, Y., and Nomura, N. 2016. Environmental factors that shape biofilm formation. Biosci. 
Biotechnol. Biochem., 80(1), 7-12. https://doi.org/10.1080/09168451.2015.1058701

Vreeland, R. H. 2012. Advances in Understanding the Biology of Halophilic Microorganisms. https://doi.org/10.1007/978-94-007-5539-0

Weiß, S., Lebuhn, M., Andrade, D., and Zankel, A. 2013. Activated zeolite - suitable carriers for microorganisms in anaerobic digestion processes? Appl Microbiol Biotechnol, 97, 3225-3238. https://doi.org/10.1007/s00253-013-4691-6

West, T. P., and Strohfus, B. 1997. Fungal cell immobilization on zeolite for pullulan production. Microbios, 91, 121-130.

Winters, Y. D., Lowenstein, T. K., and Timofeeff, M. N. 2015. Starvation-Survival in Haloarchaea. Life, 5, 1587-1609. https://doi.org/10.3390/life5041587
Woodward, J. 1988. Methods of immobilization of microbial cells. J. Microbiol. Methods, 8, 91-102.

Zerulla, K., Chimileski, S., Nather, D., Gophna, U., Papke, R. T., and Soppa, J. 2014. DNA as a phosphate storage polymer and the alternative advantages of polyploidy for growth or survival. PLoS One, 9(4). https://doi.org/10.1371/journal.pone.0094819

Zommere, Ž., and Nikolajeva, V. 2018. Immobilization of bacterial association in alginate beads for bioremediation of oil-contaminated lands. Environ. Exp. Biol., 105-111. https://doi.org/10.22364/eeb.15.09

Zur, J., Wojcieszyńska, D., and Guzik, U. 2016. Metabolic responses of bacterial cells to immobilization. Molecules, 21(7). https://doi.org/10.3390/molecules21070958. 